\title{
RELATIONSHIP MARKETING IN THE INNOVATION PROCESSES
}

\author{
Rodica Boier \\ "Gh Asachi" Technical University of Iaşi \\ Rodica_Boier@yahoo.com
}

\begin{abstract}
Inspired from the context of business-to-business markets, relationship marketing in the context of innovation have been expanded more and more to the consumer markets as well. The paper starts with a review of several most relevant studies on relationship marketing-innovation topic, from the first references to the current complex approaches. The effective stakeholder involvement in the value creation provides a more fertile ground for further successful innovations. All of the variables generating the success of a relationship marketing approachtrust, commitment, communication, seller's customer orientation and empathy, experience and satisfaction a.s.o. - are also involved, with specific particularities, in the management of the innovation and new product development processes. The paper also outline the different perspectives to understand the relationship marketing-innovation approaches, coming from the product type, its business-to-business or business-to-consumer settings, the specific industry, the actual stage of the market evolution - emerging or mature -, the level of technological novelty as dimension of technological uncertainty, the position/ status and role of stakeholders as part in the relationships, the state of the new product development process in which the interactions occurs or special issues like sustainable innovation, for profit and not-for-profit areas etc.
\end{abstract}

\section{Keywords}

innovation; new product development; relationship marketing

\section{JEL Classification}

M31

\section{Literature review}

There is always a two-way connection between innovation and relationship marketing. On one hand, the newly launched product, conceived together with the stakeholders, is likely to generate satisfaction and, hence, customer loyalty and retention with all known positive consequences. The repeated satisfaction felt by the customer, on the other hand, encourages him to expect even more from the innovative organization in what concerns the successfully launched new products. Consequently, the effective consumer involvement in the value creation provides a more fertile ground for further innovation, as result. This idea follows Peter Drucker's statement that both marketing and innovation are considered to be the two basic functions of any business enterprise. The value created by the company should be customeroriented, to generate both customer satisfaction and the expected customer relationship value.

All of the variables generating the success of a relationship marketing approach are also involved, with specific particularities, in the management of the innovation and new product development processes: trust, commitment, communication, seller's customer orientation and empathy, experience and satisfaction a.s.o. Innovationrelated benefits of the relationship marketing go from the improvement of customer 
focus, enhancement of customer knowledge and feedback and improvement of customer solutions to the enablement of product customization and personalization and, this way, better customer attraction, conversion and retention or even winningback lost customers.

The mix of relationships also apply to the specific of innovation and new product development. In this respect, according to Gummesson (2008), there are market relationships - the classic supplier-customer dyad, supplier-customer-competitior triad and the physical distribution network -, and non-market relationship - the mega relationships as platform for market relationships, concerned with the economy and society in general -, and also nano relationships, conducted at an intraorganizational level.

It is always necessary, valuable and interesting to analyse if companies really involve customers and other selected stakeholders in their new product development process, how do they do this, how profound and how long is the involvement and what results it produces, according to each phase of the innovation process. As the reality shows, new products' rate of failure continues to be high despite the fact that efforts for innovation and marketing of new products has become increasingly important to the companies' profitability. And, the primary reason for failure is still the poor understanding of the complex nature of customer needs, values and behaviors. Conversely, the companies' ability to orient themselves in successfull interactions with their individual customers will differentiate them in the future. That's why Bhalla urges for a process of „rethinking marketing and innovation” (2011).

When developing a new product, it is crucial for the new product development team to make sure they deeply understand the relational context analysis. The domain is still developing, despite several interesting researches (Fang et al., 2008; Tuli et al., 2007; Franke, 2006; Lagrosen, 2005) that have discussed methods and benefits of interacting with customers and other stakeholders. Inspired from the context of industrial market, innovation and relationship marketing have been expanded more and more to the consumer markets as well. Many academic research focused on the transactional context of the new product development, but a growing flow of research still demonstrate the importance of relationship marketing for the innovating companies (Lyu, 2012; Talet, 2012; Brito, 2011).

A strong body of literature deals with innovation and the relationship marketing specific approaches. While relationships orientation reflects a company's ability to interact with its customers and other stakeholders to take advantage of information obtained from them through successive interactions to achieve customers' loyalty through customer satisfaction regarding the new product, the innovation and new product development becomes a central issue in collaborative relationships between companies. For instance, Heide and John (1990) investigated determinants of joint action in alliances between buyers and sellers and developed a formative scale with three items to operationalize the dependent variable joint action, one of those being the component testing/ prototyping (Heide and John, 1990). Later, Anderson et al. (1994) described a business network emerging when a new product is developed and tried together with customer companies. At a higher level of generality, Ramani and Kumar (2008) linked the relationship marketing with innovation and stated that it „is a process for developing innovation capability and providing a lasting competitive advantage". Finally, several authors (Malhotra \& Singh, 2010; Laukkanen and Pasanen, 2008; Mavri et al., 2008) placed 'innovativeness' alongside other relationship marketing constructs such as mutual trust, commitment, experience, satisfaction, loyalty etc. as results from a comprehensive inventory made by Agaryia (2013). 


\section{Perspectives on the innovation-relationship marketing approach}

In the innovation processes, the relationship marketing is applied in a diversity of instances, each of them with their corresponding particularities. This diversity is comes from the product type, its business-to-business or business-to-consumer settings, the specific industry, the actual stage of the market evolution - emerging or mature -, the level of technological novelty as dimension of technological uncertainty, the position/ status and role of stakeholders as part in the relationships, the state of the new product development process in which the interactions occurs or special issues like sustainable innovation, for profit and not-for-profit areas etc. For instance, Athanassopoulos (2000) demonstrates that customer satisfaction is a function of innovation, but individual customers do not value product innovation as much as business customers do this. Or, Nambisan (2009) proposes collaboration platforms for social innovations that require collaboration among diverse networks of nonprofits, government agencies, corporations, and private citizens.

Interesting interactivites in new product development occur at the level of product novelty, on the one hand, with the embeddedness of the new product in the customer's business environment, on the other hand. According to Bonner (2010), customer interactivity is positively related to customer information quality when developing highly innovative products, but not when developing modifications or extensions of existing products. In this respect, customer interactivity was found to be positively related to information quality for highly embedded product, but not for low embedded product. During the new product development process, a complex set of relationship approaches develops between producer and customer. In a buyer-seller context, interactions have to be optimized in order to obtain as best as allocation of resources, by matching a particular relationship approach to the appropriate situational context.

Interaction management in customer integrated innovation is an opportunity for companies to supply relational service to customer and to improve customer value and relationship quality (Sun et al., 2010). But companies also need to understand how to ensure the best relational environment so that to provide the best sourcing of ideas from outside the company and even outside the industry, insights and knowledge from customers and end users, suppliers and competitors, universities, independent entrepreneurs, investors, inventors, scientists a.s.o. Besides the traditional internal sources of innovation value chain (Hansen, 2007), crosspollination (Evans 2005; Eisenhardt, 2000) and external sources (von Hippel, 2005; Kim, 2004; Chesbrough, 2003), which involve a vast and dense relational network, have gained ground and become essential solutions (ex. Linux), both involving a big and dense relationship network.

It has been fully proven, the most successful product development efforts match a set of fully understood customer problems to a cost-competitive solution to those problems. Therefore, the key is to talk to customers using appropriate methods and asking questions that customers can answer and that can provide information useful for the development of the new product (Griffin, 2013). If the objective of the customer relationship management is to find, get, and retain customers (Choy, 2003), yet it is, ultimately, a tool for understanding customer needs and behaviors. To make sure that product decisions reflect real-world needs, the customer must be brought into the design process. Integrating research, development and marketing is a good way to do that (Rust, 2010).

Understanding customer needs which drive significant product innovation is particularly challenging for the organizations developing new products. Thus, it is important to identify the dimensions of the customer interaction process which lead to more proactive organizations. In a business-to-business setting, customer interactivity 
is conceptualized as a multi-dimensional construct consisting of bidirectional communications, participation, and joint problem solving during the projects of new product development. High levels of product innovation activity are occurring through key companies leading and developing networks (Perks, 2011). The main components of such an interaction orientation can be the customer concept, the interaction response capacity, customer empowerment, and customer value management (Ramani, 2008).

Although the general strategy of developing long-term relationships is known to enhance supplier performance, it is already proven that different customers have different degrees of attraction as partners. Based on a transaction-cost analysis (how organizations can obtain maximum utility from their relationships with other organizations), Athaide and Rochard (2009) propose for the innovating companies to manage a portfolio of relationship approaches with buyers during the process of new product development because, from its three basic components - a bilateral approach, relying on a mutual exchange of information, a buyer-guided approach, and a seller-guided approach -, no one is universally desirable. According to Athaide's model, criteria to adopt a specific approach being both buyer-related (perceived buyer knowledge and prior relationship history) and innovation-related (product customization and technological uncertainty) characteristics, on the one hand, and behavioural dimensions (product co-development, pre-installation product knowledge generation, buyer education, installation support and post-installation product knowledge generation), on the other hand, the outcomes to be evaluated will be the overall seller's relationship satisfaction.

Last but not least, it is useful to approach relationship marketing in the innovation processes in its broadest sens of the roles involved - customers but also other stakeholders (consumers, suppliers, retailers, wholesalers etc.). Moreover, the whole range of aggregation levels in the relationship interactions must be considered actions, episodes, sequences, relationships and partner base -, as hierarchical levels that range from a single individual exchange to the entire relationship portfolio of a firm (Holmlund, 2004).

\section{References}

Agaryia, AK., Deepali, S. (2011), What Really Defines Relationship Marketing? A Review of Definitions and General and Sector-Specific Defining Constructs, Journal of Relationship Marketing, 10(4), 203-237.

Anderson, J.C., Haskansson, H., Johanson, I. (1994), Dyadic Business Relationships Within a Business Network Context, Journal of Marketing, 58 (October), 115.

Atahaide, GA., Rochard RK. (2009), Managing Seller-Buyer Relationships during New Product Development, Journal of Product Innovation Management, 26, 566-577.

Athanassopoulos, DA. (2000), Customer satisfaction cues to support market segmentation and explain switching behaviour, Journal of Business Research, 47, 191-207.

Bhalla, G. (2011), Collaboration and Co-creation: New Platforms for Marketing and Innovation, New York, Springer Science+Business Media, LLC.

Bonner, J. M. (2010), Customer interactivity and new product performance: moderating effects of product newness and product embeddedness, Industrial Marketing Management, 39(3), 485-492. 
Brito, C. (2011), Relationship marketing: old wine in a new bottle?, Innovative Marketing, 7(1), 66-77.

Chesbrough, H. (2003), Open Innovation: The New Imperative for Creating and Profiting from Technology, Boston, Harvard Business School Press.

Choy, KL., Lee, WB., Lo, V. (2003), Design of an intelligent supplier relationship management system: A hybrid case based neural network approach, Expert Systems with Applications, 24, 225-237.

Drucker, P. (1954), The Practice of Management, New York, Harper \& Row Publisher.

Eisenhardt, K.M., Galunic, D.C. (2000), Coevolving: At Last, a Way to Make Synergies Work, în Harvard Business Review, 78(1), 91-100.

Evans, P., Wolf, B. (2005), Collaboration Rules, Harvard Business Review, JulyAugust, 96-104.

Fang, E., Palmatier, RW., Evans, KR. (2008), Influence of customer participation on creating and sharing of new product value, Journal of the Academy of Marketing Science, 36, 322-336.

Franke, N. (2006), Finding Commercially Attractive User Innovations: A Test of Lead-User Theory, Journal of Product Innovation Management, 23(4), 301315.

Griffin, A. (2013), Obtaining customer needs for product development, in Kahn, KB. (2013), The PDMA Handbook of New Products Development, $3^{\text {rd }}$ Edition, Hoboken, NJ, Wiley, 2010, 213-230.

Gummesson, E. (2008), Total Relationship Marketing: Marketing management, relationship strategy, CRM, and a new dominant logic for the value-creating network economy, $3^{\text {rd }}$ Edition, Oxford, Butterworth-Heinemann, Elsevier Ltd.

Hansen, MT., Birkinshaw, J. (2007), The Innovation Value Chain, Harvard Business Review, Harvard Business Review on Inspiring \& Executing Innovation, Boston, Harvard Business School Publ. Co., 89-118.

Heide, JB., John, G. (1990), Alliances in Industrial Purchasing: The Determinants of Joint Action in Buyer-Supplier Relationships, Journal of Marketing Research, 27 (February), 24-36.

Holmlund, M. (2004), Analyzing business relationships and distinguishing different interaction levels, Industrial Marketing Management, 33, 279- 287.

Kim, C., Mauborgne, R., (2004), Blue Ocean Strategy, Boston, Harvard Business School Press.

Laukkanen, T., M. Pasanen (2008), Mobile banking innovators and early adopters: How they differ from other online users? Journal of Financial Services Marketing, 13(2), 86-94.

Lagrosen, S. (2005), Customer involvement in new product development: A relationship marketing perspective, European Journal of Innovation Management, 8(4), 424 - 436.

Lyu, Jr-J., Chao, HL., Chen, CW., Huang, LY. (2012), Developing a Customer Relationship Management Model for Better Health Examination Service, Nang Yan Business Journal, 1-06, 38-46.

Malhotra P., Singh B. (2010), An analysis of Internet banking offerings and its determinants in India, Internet Research, 20(1), pp. 87-106.

Mavri, M., Ioannou, G. (2008), Customer switching behaviour in Greek banking services using survival analysis, Managerial Finance, 34(3), 186-197.

Nambisan, S. (2009), Virtual Customer Environments: IT-Enabled Customer Coinnovation and Value Co-creation, in Nambisan, S. (Ed.), Information 
technology and product development, Annals of information systems, 5(2), 109-127.

Perks, H., Moxey, S. (2011), Market-facing innovation networks: How lead firms partition tasks, share resources and develop capabilities, Industrial Marketing Management, 40(8), 1224-1237.

Ramani, G., Kumar, V. (2008), Interaction Orientation and Firm Performance, Journal of Marketing, 72(1), 27-45.

Rust, RT., Moorman, C., Bhalla, G. (2010), Rethinking Marketing, Harvard Business Review, 88(1), 94-101.

Sun, H., Yau, HK., MingSuen, EK. (2010), The Simultaneous Impact of Supplier and Customer Involvement on New Product Performance, Journal of Technology Management \& Innovation, 5(4), 70-82.

Talet, AN. (2012), KM Process and CRM to manage Customer Knowledge Relationship Management, International Proceedings of Economics Development \& Research IPEDR, Vol. 29, Singapore, IACSIT Press, 60-67.

Tuli, KR., Kohli, AK., Bharadwaj, SG. (2007), Rethinking Customer Solutions: From Product Bundles to Relational Processes, Journal of Marketing, 71(3), 1-17.

von Hippel, E. (2005), Democratizing innovation, The MIT Press, Cambridge, Massachusetts. 